Stručni rad

BOJAN JANJANIN

Prihvaćeno 5. 12. 2017. JELENA BEBAN-BRKIĆ

\title{
Analiza izmjere Keopsove piramide
}

\section{Survey Analysis of the Great Pyramid ABSTRACT}

The topic of this paper is an analysis of the survey of Cheops pyramid (also known as the Great pyramid), the most significant of the three pyramids of the Giza complex, the archeological site on the plateau of Giza, situated on the periphery of Cairo. It is assumed that Cheops as well as Khafre and Menkaure pyramids were built around 2686 - 2181 BC, known in the history as the Old Kingdom of Egypt. Our goal was to collect data about geodetic survey of Cheops pyramid and analyze it. Along with that, several hypotheses related to the construction method of the pyramid and possible purposes of the construction itself are described.

When analyzing the survey, two numbers, also called "two treasures of geometry", are constantly appearing, these are the number $\mathrm{Pi}(\pi)$ and the Golden ratio or golden number $\mathrm{Fi}(\varphi)$. One of the chapters is dedicated to these numbers.

Key words: geodetic survey, analysis of collected data, Ludolph's constant, Golden ratio

MSC2010: 00A99, 01A16, 86A30

\section{Uvod}

Keopsova piramida, poznata i pod nazivom Velika piramida, najstarije je od sedam svjetskih čuda Starog svijeta i jedino koje je očuvano u potpunosti. To je najstarija $\mathrm{i}$ najveća piramida u Gizi, danas predgrađu Kaira.

Velika piramida podignuta je na umjetno poravnatoj kamenoj uzvisini. Prvotnom visinom od 146,7 metara bila je najviša građevina na svijetu sve do izgradnje Eiffelovog tornja (1889.). Baza piramide nije savršen kvadrat, ali najveće odstupanje između stranica koje su duge oko 230 metara iznosi nevjerojatnih 20 centimetara, odnosno $0,09 \%$.

Točnost orijentacije prema četiri strane svijeta također zapanjuje jer pomoću pronađenih podataka odstupanje iz-

\begin{abstract}
Analiza izmjere Keopsove piramide
SAŽETAK

Tema ovog rada jest analiza izmjere Keopsove piramide, najznačajnije od triju većih piramida Giza kompleksa, arheološkog nalazišta na visoravni Giza, na periferiji Kaira. Pretpostavlja se da je Keopsova, kao i Kefrenova i Mikerinova piramida građena u periodu 2686. - 2181. pr. Kr., u povijesti poznatom kao Staro egipatsko Kraljevstvo. Cilj nam je bio prikupiti podatke o geodetskoj izmjeri Keopsove piramide te ih analizirati. Uz to je opisano i što je prethodilo izgradnji takve monumentalne građevine. Navedeno je nekoliko hipoteza koje su vezane za način gradnje piramide te su opisane i moguće svrhe same gradnje. Pri analizi izmjere neprestano se pojavljuju dva broja koja su nazivana i "dva blaga geometrije", a to su broj Pi $(\pi)$ te Zlatni rez odnosno zlatni broj $\mathrm{Fi}(\varphi)$. Upravo tim brojevima posvećeno je jedno poglavlje ovog rada.
\end{abstract}

Ključne riječi: geodetska izmjera, analiza prikupljenih podataka, Ludolfova konstanta, zlatni rez

nosi $0,06 \%$. Današnji stručnjaci tvrde da je takvu točnost moguće ostvariti pomoću modernih laserskih uređaja i dobrog poznavanja astronomije.

Piramida se prostire na površini od $53000 \mathrm{~m}^{2}$, volumen joj se procjenjuje na 2,6 milijuna kubnih metara, a masa iznosi impresivnih 6,3 milijuna tona. Za izgradnju piramide upotrijebljeno je približno 2,3 milijuna kamenih blokova koje imaju prosječnu masu koja iznosi 2,6 tona. Prema vjerovanjima egiptologa za izgradnju piramide bilo je potrebno samo 20 godina.

Izgrađena je od različitog materijala koji je bio pribavljen iz raznih dijelova Egipta. Mnogi blokovi morali su biti dopremljeni do svog odredišta s više od tisuću kilometara udaljenosti. 
U analizi izmjere često se pojavljuju brojevi 3,141 i 1,618. Navedeni brojevi se tamo ne nalaze slučajno, upravo ti brojevi su jedni od temelja na kojima leži geometrija Velike piramide.

Uvriježeno je mišljenje da su piramide izgrađene kao grobnice faraona te da su služile kako bi se preminuli faraoni povezali s duhovnim svijetom. Ljudi iz Drevnog Egipta vjerovali su da je smrt na Zemlji bila početak putovanja prema sljedećem "životu".

Pri pisanju ovog poglavlja služili smo se sljedećom literaturom: [4], [8], [18] i [20].

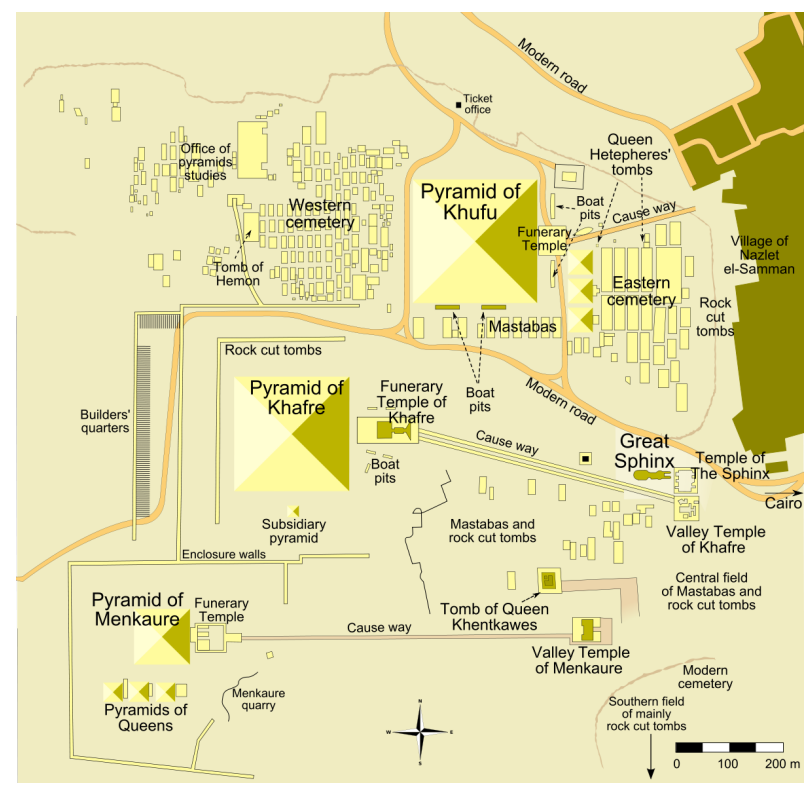

Slika 1: Mapa kompleksa piramida u Gizi (Izvor: [28])

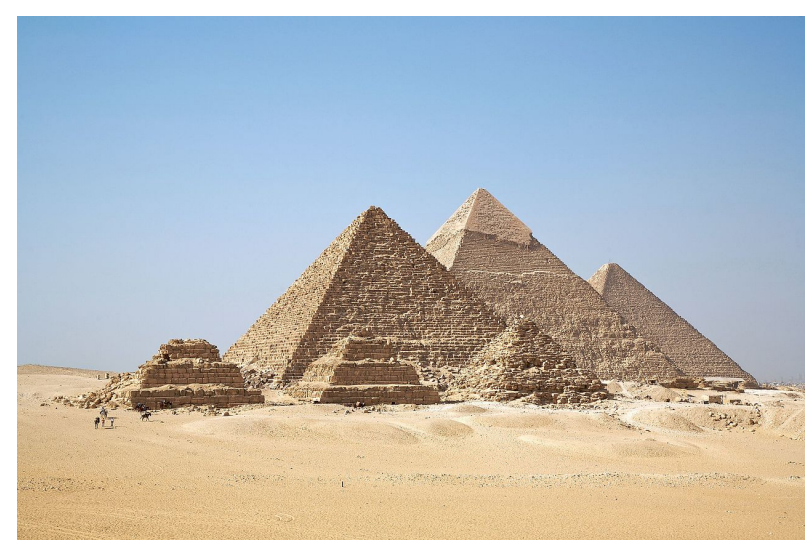

Slika 2: Fotografija kompleksa piramida u Gizi (Izvor: [28])

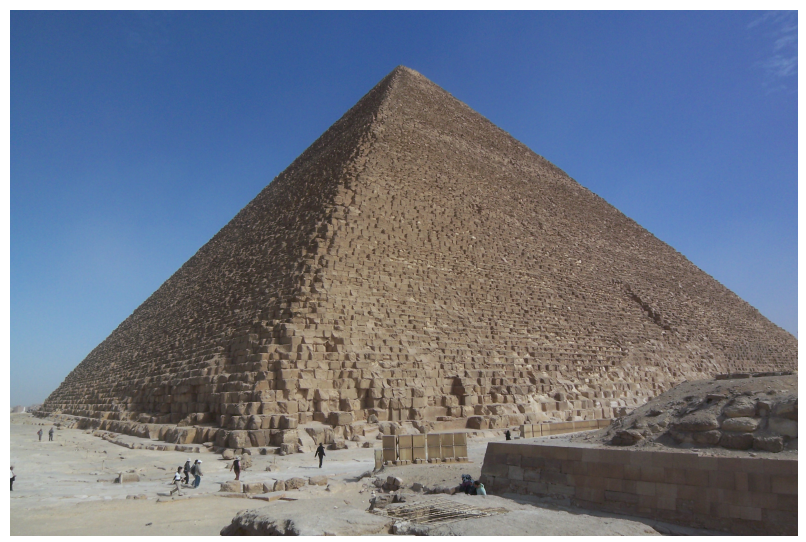

Slika 3: Fotografija Keopsove piramide (Izvor: autori)

\section{Značenje riječi piramida}

Riječ piramida izvodi se iz grčke riječi PYRAMIS (što u prijevodu i znači piramida). U literaturi se nailazi na mišljenje da je riječ pyramis izvedenica egipatske riječi $P E R-E M-U S$, pronađene u matematičkom papirusu poznatom po nazivu $R h i n d^{1}$. Ta je riječ per-em-us opisana u egipatskoj matematičkoj raspravi kao naznaka visine piramide. Prevedena doslovce znači "ono što ide (ravno) gore" (od nečega označenog konačnim slogom US). Nažalost značenje tog sloga nije poznato i zato je riječ samo djelomično jasna. Egiptolozi ovo tumačenje smatraju neprihvatljivim te riječ pyramis prihvaćaju kao izvorno grčku riječ bez ikakve povezanosti s egipatskom terminologijom.

\subsection{Sedam svjetskih čuda}

Sedam svjetskih čuda jesu:

1. Velika piramida u Gizi (oko 2550. godina pr. Kr., Egipat)

2. Babilonski viseći vrtovi (oko 600. godina pr. Kr., današnje područje između Bagdada i Perzijskog zaljeva)

3. Fidijin kip Zeusa u Olimpiji (oko 440. godina pr. Kr., južna Grčka)

4. Artemidin hram u Efezu (oko 550. godina pr. Kr., današnja Turska)

5. Grobnica karijskog (Karija, maloazijska perzijska provincija) kralja Mauzola u Halikarnasu (oko 350. godina pr. Kr., današnji Bodrum, grad na obali Egejskog mora, Turska)

\footnotetext{
${ }^{1}$ Rhind - staroegipatski papirus kojeg je pronašao Aleksandar Henry Rhind, škotski krijumčar egipatskih relikvija, 1858. godine u ruševini manje građevine. Datiran je u vrijeme oko 1650. godine pr. Kr. iz XV. dinastije. Pismo kojim je pisano je hijeratičko. Od 1863. godine nalazi se u Britanskom muzeju.
} 
6. Kolos s Rodosa (oko 280. godina pr. Kr., grčki otok Rodos)

7. Aleksandrijski svjetionik (oko 280. godina pr. Kr., Egipat).

\section{Nastanak piramida i motivi gradnje}

Premda se piramide nalaze na svim kontinentima svijeta, siguran razlog gradnji ostaje nejasan i nepoznat. Mnogi istraživači smatraju da postoji izgubljena povezanost između egipatskih piramida s piramidama u Južnoj Americi i Meksiku, s jakom asocijacijom da ih je gradio po značenju isti arhitekt [13].

Građene su uglavnom od kamena vapnenca dok su unutrašnje prostorije od granita. Blokovi na vrhovima su bili od granita ili bazalta obloženi zlatom, srebrom ili legurom zlata i srebra. Vanjske površine su bile polirane da bi bile vidljive iz daljine.

Nesuglasice o izvođenju riječi piramida/pyramis neznatne su u usporedbi s onima koje izaziva tumačenje svrhe postojanja samih piramida. Egiptolozi tvrde da su piramide grobnice. Peruolozi i drugi arheolozi koji istražuju u Srednjoj Americi, tvrde da su piramide bile rezonatori ili spremišta energije. Oni tvrde da se frekvencija zračenja zemlje, uključujući pravce magnetskih silnica i kozmičkih zračenja spajaju unutar piramidalne strukture stvarajući udarne frekvencije (na jednak način kao i što dvije tipke klavira, udarene skupa, stvaraju treću ili udarnu frekvenciju). Udarna frekvencija, smatraju, može stvoriti energetsko zračenje.

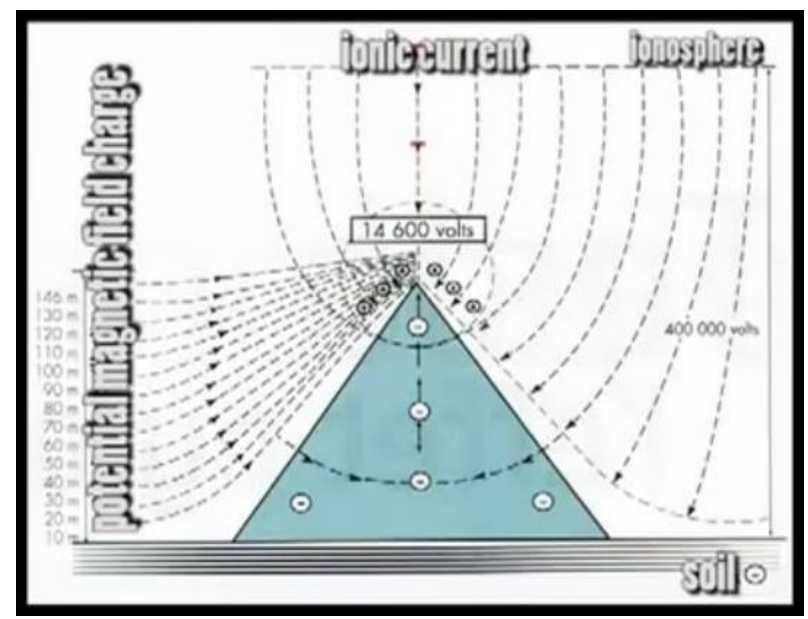

Slika 4: Prikaz smjera djelovanja raznih sila na Veliku piramidu (Izvor: [15])

Nameće se pitanje: za što je ta energija korištena i kako su arhitekti znali da se piramide mogu koristiti na takav način? Do danas na žalost ne postoje jednoznačni odgovori na gornja pitanja. U ovom članku ćemo se se bazirati na činjenicama koje se mogu povezati s matematikom i fizikom uz pomoć podataka koji su dobiveni geodetskom izmjerom.

\section{1 Četvrta dinastija}

Egipatska povijest dijeli se u dinastije. Od Preddinastijskog i Ranodinastijskog perioda (4. tisućljeće pr. Kr.) pa sve do perzijske vlasti i Helenističko-rimskog perioda (4. st. pr. Kr.), postojalo je ukupno trideset dinastija, kojima su vladali brojni vladari. Razdoblje u kojem su građene piramide se naziva Staro egipatsko kraljevstvo (2686. 2181. pr. Kr). Drevni Egipat dostigao je civilizacijski vrh u tom razdoblju na području doline rijeke Nil. Ono obuhvaća vrijeme između treće i šeste dinastije. Period koji se odnosi na četvrtu dinastiju često je nazivan i Zlatno doba. Uobičajeno se smatra da je četvrta dinastija trajala od 2613. pr. Kr. do 2455. pr. Kr. Vladari/faraoni četvrte dinastije sastoje se od sedam generacija memfiskih kraljeva (Memphis - tadašnja prijestolnica, ruševine se nalaze 19 km južno od Kaira). O dinastijama Drevnog Egipta vidi u [7], [9] i [10].

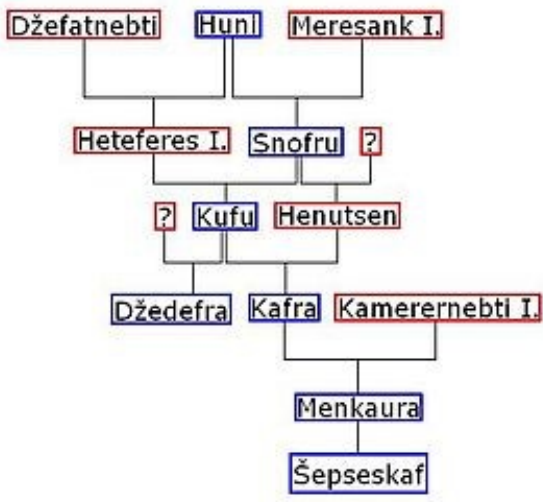

Slika 5: Na prikazu obiteljskog stabla plavim pravokutnicima su označeni faraoni, a imena kraljica crvenim. (Izvor: [29])

Uz izgradnju triju piramida na platou Gize povezani su sljedeći vladari:

Kufu, Sufis ili punim imenom Hnum-Kufu; (2589. 2566. pr. Kr.); najpoznatiji prema grčkoj inačici imena Keops.

Iza navodnog vlasnika jednog od svjetskih čuda - Velike piramide u Gizi nije na žalost ostao nikakav prikaz. Tek se za jednu minijaturnu statuetu visine $5 \mathrm{~cm}$ smatra se da bi mogla prikazivati Keopsa. Za razliku od Keopsa, likovi nekih mnogo manje važnih vladara poznati su preko mnogih statua i slikarija. Tako je primjerice, Tutankhamona, faraona dječaka čije kraljevstvo nije ostavilo nikakva traga u povijesti, zbirka dragocjenosti iz njegove grobnice učinila simbolom faraonskog Egipta. Prema navodima jednog papirusa iz Novog kraljevstva Keops je sam izradio planove 
za gradnju velike piramide u Gizi. Grčki povjesničar Herodot (484. - 424. pr. Kr.) govori o njemu kao tiraninu koji je s pomoću mnogobrojnih tisuća robova izgradio svoju piramidu.

Džedefra (Rađedef) (2566. - 2558. pr. Kr.)

Keopsov sin i nasljednik. Prvi faraon koji nosi titulu "sin Sunca" koja je od tada korištena u tradicionalnom faraonskom nazivlju do kraja egipatske povijesti. Smjestio je svoju kultnu $b a r k u^{2}$ podno velike piramide. Njegova piramida ostala je nezavršena.

Kafra (Kefren) (2558. - 2532. pr. Kr.)

Pretpostavlja se da je on također bio Keopsov sin. Izgradio je drugu piramidu u Gizi, dok treća pripada kralju Menkauri (Mikerin) (2532. - 2503. pr. Kr.).

\subsection{O lokaciji piramida}

Velika piramida nalazi se na $30^{\circ}$ sjeverne zemljopisne širine, na zapadnoj obali Nila na visoravni Giza, danas u predgrađu Kaira. Plato je dovoljno povišen kako kompleks ne bi poplavio nabujalim rijekama, a opet dovoljno blizu kako bi se prijevoz tereta mogao njima vršiti. Svako izlijevanje Nila "približilo" bi piramidu rijeci na udaljenost od nekoliko stotina metara. Drugi razlog izbora lijeve obale Nila jest čvrsti kameni fundament koji je mogao nositi čitav kompleks piramida. Ispitivanje tla i pronalazak čvrste kamene podloge zahtijevalo je nevjerojatno široko znanje iz mnogih područja vezanih s ispravnim geološkim procjenjivanjem.

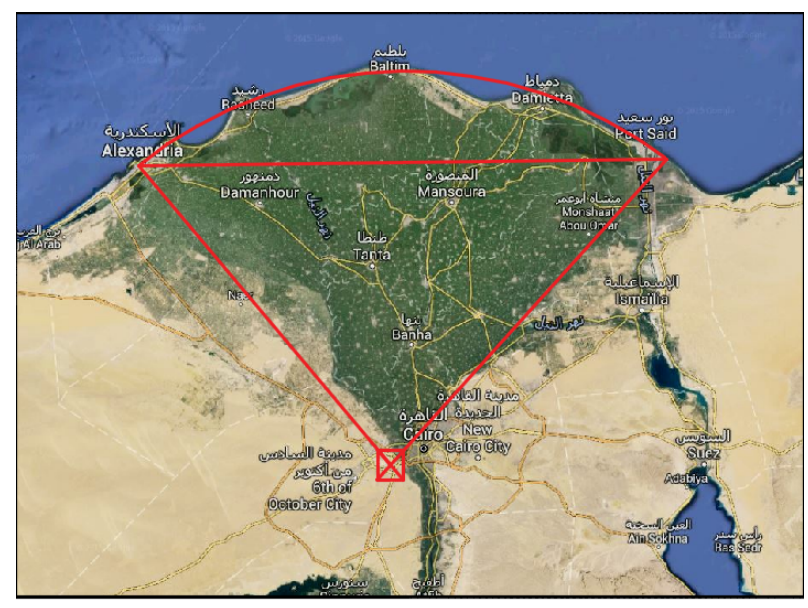

Slika 6: Crvene linije prikazuju produljene dijagonale baze piramide; idealno zatvaraju deltu rijeke Nil (autori, u programu AutoCAD), (Izvor: [30])
Osim toga egiptolozi, kartografi i ini istraživači uspostavili su niz odnosa, pravilnosti vezanih za njen geografski položaj. Navodimo neke od njih. Uzme li se vrh piramide za središte oko kojeg se opiše luk koji obuhvaća cijelo područje delte rijeke Nil, produžene dijagonale Piramide potpuno zatvaraju područje Delte (slika 6).

Kartografi navode: ako se pri određenoj projekciji piramida uzme kao središnja točka za iscrtavanje dviju međusobno okomitih linija na karti Zemlje, dobije se da su kopnena masa i oceani pravedno raspodijeljeni na četiri kvadrata (slika 7).

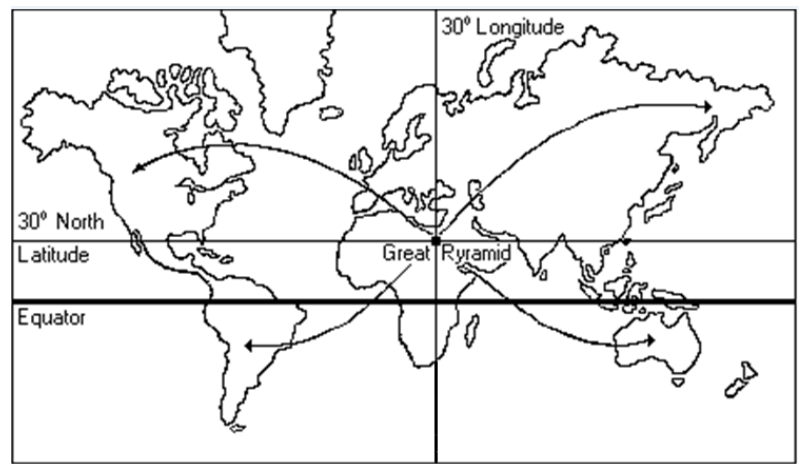

Slika 7: Prikaz lokacije piramide s obzirom na ekvator (Izvor: [27])

\subsection{Plato - čišćenje i priprema za izgradnju}

Nakon što je izabrano mjesto gdje će piramide biti izgrađene trebalo je očistiti velike količine pijeska i kamenja koji su pokrivali čvrsti kameni temelj, a zatim čitavo područje iznivelirati.

Poravnanje je toliko točno da Velika piramida odstupa od savršene ravnine ${ }^{3}$, prema raznim autorima, u visinskom smislu oko $1,5 \mathrm{~cm}$. U odnosu na dužinu do $230 \mathrm{~m}$, pogreška od $1,5 \mathrm{~cm}$ zaista se može smatrati beznačajnom. Zaokruži li se $1,5 \mathrm{~cm}$ na $0,01 \mathrm{~m}$ dolazi se do izračuna da odstupanje iznosi $0,004 \%$. Ta se mala pogreška može vrlo lako mjeriti sa današnjim modernim tehnologijama i sofisticiranim uređajima.

Smatra se da je nivelacija izvršena urezivanjem brazdi u prirodnoj stijeni, nakon čega su punjene vodom. Tlo je tada brušeno sve dok nije postignuta jednaka razina $s$ površinom vode.

Idući korak je bilo mjerenje područja kako bi se osigurala savršeno kvadratična baza i to duž osi sjever - jug odnosno istok - zapad. Napomenimo da je kompas u to doba bio nepoznat te da su graditelji na raspolaganju imali samo trokut i visak. Unatoč tome, Keopsova piramida bi rotacijom u

\footnotetext{
${ }^{2}$ Jedan od običaja pri pokopu faraona bilo je pohranjivanje barke u grobnicu. Taj je običaj bio povezan s vjerovanjem da će on nakon smrti putovati na barci nebeskim Nilom.

${ }^{3}$ Savršena ravnina u geodeziji bi predstavljala onu ravninu koja je paralelna s određenom nivo plohom. Nivo ploha je ploha koju možemo obići bez uspinjanja ili spuštanja i na kojoj je radnja sile teže za točkastu masu, koja se po njoj kreće, jednaka nuli. Ta ploha je u svim svojim točkama okomita na smjer vektora sile teže.
} 
iznosu od svega 3 minute doživjela pomak koji bi joj osigurao idealan smještaj s obzirom na strane svijeta kao što se vidi na slici 8 . Zbog toga se pretpostavlja da je egipatsko astronomsko znanje bilo izvan dosega znanstvenih ograničenja današnje civilizacije.

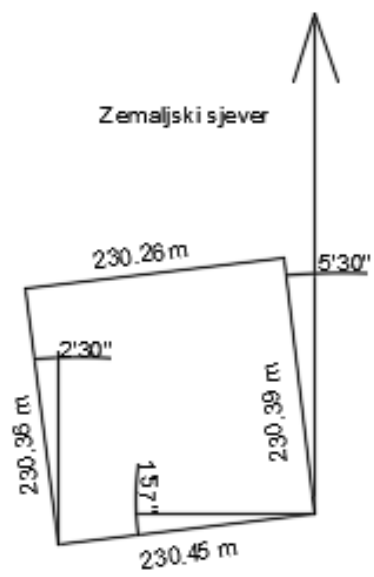

Slika 8: Prikaz odstupanja piramide s obzirom na strane svijeta (nacrtali autori)

\section{Gradnja Velike piramide}

\subsection{Građevni materijal}

Za potrebe izgradnje piramida dopremani su vapnenački blokovi iz kamenolomu u Turi, na istočnoj obali Nila, te blokovi granita iz blizine Asuana, dalje niz Nil.

Stručnjaci tvrde da su radnici u kamenolomu, radeći u malenim tunelima prokopanim duboko u ležište stijene, iskapali, klesali, cijepili, pričvršćivali klinovima i razbijali goleme kamene blokove. Nakon toga monolite su sjekli i glačali sve dok nisu dobili gotovo savršene kocke.

Međutim, ostaje otvoreno pitanje koji su alat pritom upotrebljavali. Vađenje tih golemih kamenih blokova, mase od dvije do sedamdeset tona, nije se moglo izvesti pomoću jednostavnog alata kojeg su arheolozi pronašli u kamenolomima. O tome postoji niz hipoteza, među kojima prevladava teorija klina.

Prema toj teoriji graditelji su dlijetom dubili rupe sve dok u njih ne bi mogli ugurati drveni klin. Drvo bi tada natopili vodom zbog čega se ono počelo širiti. Uslijed širenja nastala bi pukotina i taj kamen okružen klinovima bi se odvajao od stijene. Kao i sve ostale hipoteze, i ova ima svoje nedostatke i nedovoljno objašnjava način na koji su radnici u kamenolomu lomili kamen. Naime, svi alati su misteriozno nestali, ili su namjerno uklonjeni kada je sve bilo gotovo. To je tim čudnije s obzirom da je izgrađen velik broj piramida i upotrijebljeni su milijuni kamenih blokova (slika 9).

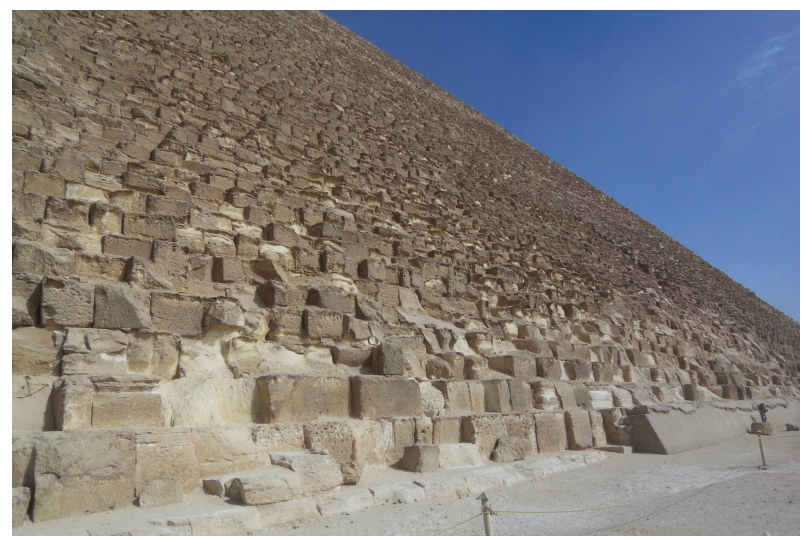

Slika 9: Fotografija prikazuje kamene blokove pri osnovici Keopsove piramide (Izvor: autori)

\subsection{Transport kamenih blokova}

Nakon odvajanja kamenih blokova slijedi problem transporta do odredišta. Stručnjaci tvrde da ih je bilo moguće transportirati jedino za vrijeme poplava Nila. Navodi se da su stotine, ako ne i tisuće ljudi na obali Nila vukli konopce koji su bili povezani s velikim brodovima te su tako usmjeravali brod na određeno mjesto.

Međutim, smatra se da je Egipćanima veći problem bio kopneni prijevoz. Pomicanje blokova po pijesku bio je zaista mukotrpna zadaća. Iako postoje nesuglasice o tome da li su u doba gradnje piramida Egipćani upotrebljavali kotač, odnosno vozila s kotačima, činjenica je da i ako su postojala, takva bi se vozila po pijesku prilično teško gibala. Jedini dokaz u tom smislu je slika u grobnici iz razdoblja pete dinastije u Kemhesetu u Saqqari, koja prikazuje jurišne ljestve na kotačima (slika 10).

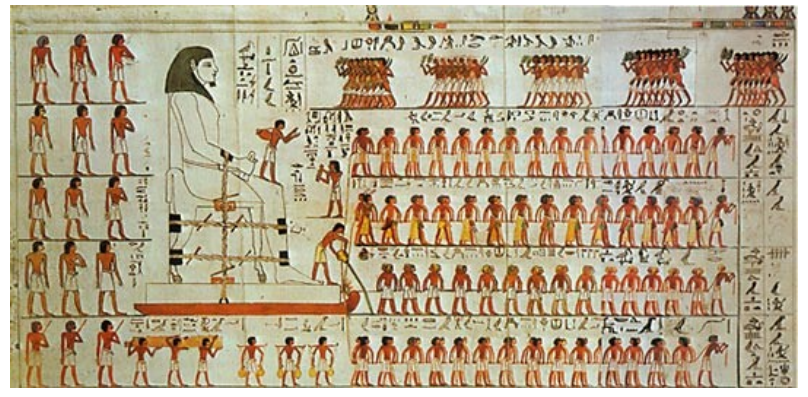

Slika 10: Prikaz uporabe saonica ispred kojih se prolijevala voda ili ulje (Izvor: [25])

Od raznih teorija koje se bave problemom transporta kamenih blokova našu je pažnju privukla ona koju je zastupao Robert Nelson (1794. - 1873.), znanstvenik iz New Jerseya. On je tvrdio da je na Nilu, negdje ispod kamenoloma, postojala brana zbog koje je u vrijeme poplava veliki dio zemlje pokrivala voda neznatne dubine od 90 do 120 $\mathrm{cm}$. Takva je brana mogla ublažiti sve probleme plovidbe, dok je kontrolom njezine razine vodu bilo moguće dovesti 
toliko blizu kamenoloma koliko je potrebno. Time bi se objasnilo postojanje školjki i drugih okamenjenih riječnih fosila pronađenih na različitim dubinama oko temelja Velike piramide. Nelson je nadalje tvrdio da je usporedno $s$ rastom Piramide, područje bilo poplavljeno do visine potrebne za usklađivanje položaja brodova i Piramide. Kameni blok s broda bi jednostavno skliznuo na svoje mjesto. Može se uočiti sličnost između te tehnike i sistema kojim danas funkcioniraju brane. Ta teorija je toliko jednostavna da isključuje gradnju s pomoću kosih prilaza, potrebu za moćnim i složenim ručnim dizalima ali i teoriju saonica.

Zagovornik Roberta Nelsona $u$ današnje vrijeme je inežnjer građevine Chriss Massey. Chriss Massey još pojednostavlja teoriju na način da iz funkcije izbacuje brodove te uvodi plovke. Plovak je napravljen od životinjskog tkiva koji je napunjen zrakom te pričvršćen za kamene blokove omogućuje plutanje bloka na površini vode (slika 11).

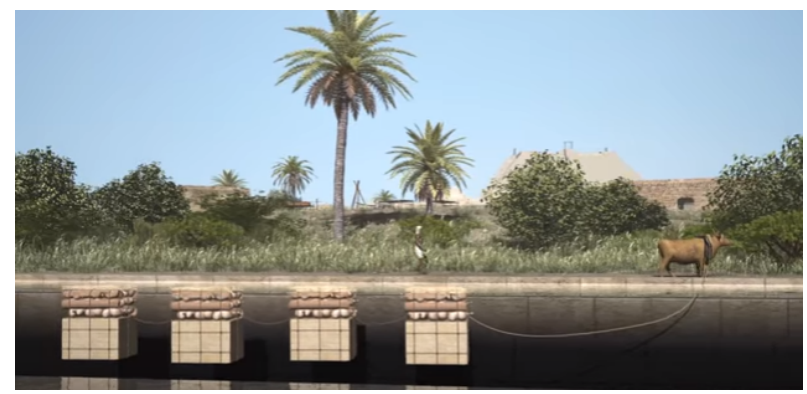

Slika 11: Prikaz mogućeg prijevoza kamenih blokova rijekom Nil. Na kamenim blokovima se nalaze životinjska tkiva ispunjena zrakom. (Izvor: [31])

\subsection{Mogući načini gradnje}

Način gradnje koji se primjenjivao u 4. dinastiji bio je složeniji, a time i neusporedivo zahtjevniji od onog prijašnjih piramida. Velika piramida zanimala je Herodota koji je Egipat posjetio u 5. stoljeću pr. Kr., vremenu koje bi približno odgovaralo 21. dinastiji, a to znači vremenu od barem 2000 godina nakon podizanja te fascinantne građevine. On u svom zapisu navodi jedan od mogućih načina gradnje piramide; pomoću sprava izrađenih od istesanih kratkih greda koje su služile za podizanje kamenih blokova sa stube na stubu te da je prvo bio dovršen vrh piramide pa ispod njega središnji dio koji leži na zemlji. Osim toga, u njegovom se zapisu prvi put spominje duljina gradnje. On je smatrao da je za dovršenje same piramide (bez ostatka kompleksa) bilo potrebno dvadeset godina (Hist. II. 125).

Gradnja piramida nastavlja se i u vrijeme pete i šeste dinastije, ali ona više veličinom i složenosti ni približno ne slijedi one piramide izgrađene za vrijeme ranijih dinastija. Za razliku od prijašnjih piramida novoizgrađene piramide ispisane su vjerskim tekstovima. Nakon toga, za vrijeme prijelaznog doba između starog i srednje kraljevstva gradnja piramida nestaje.

\subsubsection{Poluga}

Inženjer Olaf Tellefsen (1909. - 1990.) tvrdi kako Egipćani pri gradnji piramide nisu koristili rampe i saonice te da je za podizanje piramide bilo potrebno samo 3000 radnika. Tellefsen zasniva svoje argumente na promatranju trojice ljudi koji su pomicali veliki kamen prema obali Nila rabeći primitivan alat - polugu dugačku 6 metara. Uz pomoć poluge i valjaka podizali su blokove teške i to 2 tone. Tellefsen je zaključio da je posrijedi tehnička vještina koju su ljudi naslijedili iz prošlosti. Shodno tomu čitav je piramidalni kompleks mogao biti izgrađen uporabom poluge.

Kent Weeks i I.E.S. Edwards, poznati i priznati suvremeni egiptolozi, odbacuju Tellefsenovu hipotezu ostajući pri onoj nasipa, rampi i saonica. Svoje spoznaje baziraju na pronalasku rampi u blizini piramida, koje imaju zakošenje od $150^{\circ}$, što smatraju "iznimno pogodnim kutom za povlačenje blokova”.

Važno je napomenuti kako mnoga arheološka nalazišta sadrže ostatke stare i nekoliko tisuća godina te da će u svjetlu otkrića ugljika $14\left({ }^{14} \mathrm{C}\right)^{4}$ određivanje njihove starosti biti podvrgnuto daljnjim ispitivanjima. Ipak, kako u [24] ističu Ines Krajcar Bronić et al., "Treba naglasiti da se metodom ${ }^{14} \mathrm{C}$ odre duje starost materijala, a ne predmeta koji je od tog materijala izraden, Na primjer, ako se određuje starost drvenog kipa, ${ }^{14} \mathrm{C}$ metodom odredit ćemo vrijeme kad je drvo prestalo rasti, a ne kad je neki umjetnik izradio kip. Ovom bi se metodom uspješno mogli datirati različiti organski materijali,kao što su drvo, drveni ugljen, treset, bilje, žito, tkanine, kosti, stari do 60000 godina. Tako se mogu odrediti i starosti sekundarnih karbonata (sige, sedra, jezerski i morski sedimenti), školjaka, koralja, itd."

\subsubsection{Gradnja iznutra}

Zanimljivu ideju o gradnji piramide prezentirao je francuski arhitekt Jean-Pierre Houdin (rođen 1951. godine), koji je pomoću 3D softvera razvijenog u Dassault Systemes (tvrtka koja se bavi razvojem 3D tehnologije) zaključio da je piramida građena pomoću spiralne rampe koja se nalazila unutar piramide, i još uvijek bi trebala biti tamo. Prema njemu, prva trećina piramide napravljena je vanjskom velikom rampom. U isto se vrijeme gradila i unutrašnja rampa, otprilike 3 metra široka i s nagibom od $7 \%$. Kako je piramida rasla i počela se raditi iznutra, korišteno je kamenje od kojeg je napravljena vanjska rampa.

\footnotetext{
${ }^{4}$ Ugljik 14 je radioaktivni izotop ugljika s jezgrom koja sadrži 6 protona i 8 neutrona. Prisutan je u ogranskim materijalima i osnova je za određivanje starosti organskog uzorka u arheologiji i geologiji.
} 


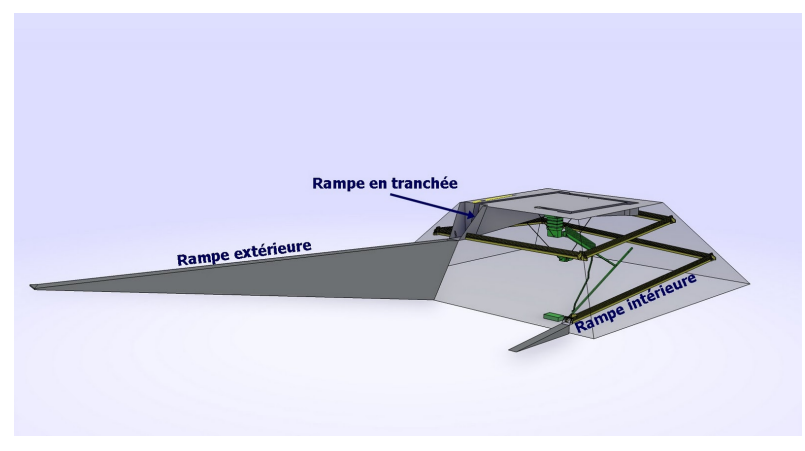

Slika 12: Prikaz vanjske rampe koja je služila u izradi donjeg dijela piramide te unutarnje rampe koja je služila pri izradi piramide nakon što je vanjska rampa dosegnula nagib od $7^{\circ}$ (Izvor: [16], [17])

Prema Houdiniju, od samog su početka planirane tri komore u piramidi, na različitim razinama, pretpostavlja iz razloga kako bi Keops mogao biti dostojno pokopan u slučaju da umre tijekom gradnje. Prva je uklesana u samo postolje piramide, ispod razine tla, prije nego što je gradnja i počela. Zatim se počela raditi tzv. Kraljičina odaja, a deset godina iza nje i Kraljeva odaja, u samom srcu piramide. Tu je, na kraju, i položen Keopsov sarkofag.

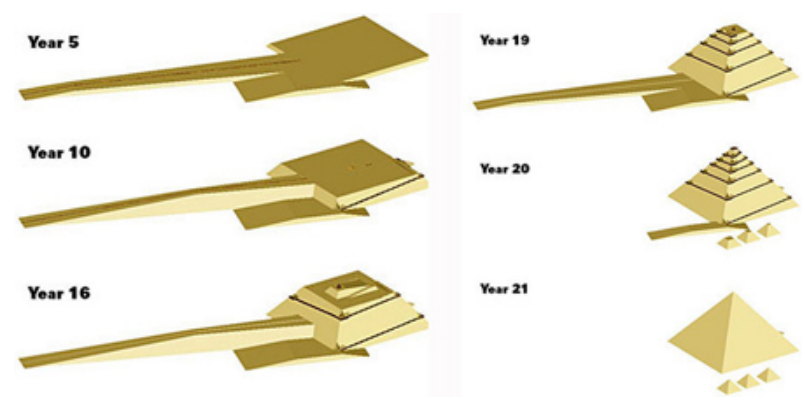

Slika 13: Prikaz napredovanja gradnje piramide kroz godine (Izvor: [16])

\subsection{Broj ljudi i vrijeme koje je bilo potrebno za izgradnju piramide}

Veliku piramidu je prema Herodotu gradilo 400000 radnika. On pretpostavlja da su ljudi bili podijeljeni u četiri skupine a svaka je imala 100000 ljudi i provodila je na gradilištu 4 mjeseca. Ako se ovaj broj prihvati kao točan treba imati na umu da tih 400000 ljudi mora negdje biti smješteno, mora biti opskrbljeno hranom i pićem te imati sve potrebno za održavanje zdravstvene higijene. Međutim, nedostaje nalaz o ikakvoj strukturi ili građevini koja se koristila za smještaj tako velikog broja radnika. Postoji i mogućnost da radnici nisu živjeli na gradilištu nego da su tamo svakodnevno dolazili s drugog mjesta, što otvara pitanje načina prijevoza i dužine putovanja. Herodotov navod o 400000 ljudi zaposlenih na izgradnji piramide osporavaju mnogi, jer bi, kako se smatra da je broj žitelja u Starom kraljevstvu bio između 1,5 i 2 milijuna značilo da je zdanje gradila $1 / 4$ do $1 / 5$ cjelokupne populacije. Stoga je 100000 ljudi puno realniji broj.

Nekolicina autora smatra da su nakon gradnje piramide radnici pogubljeni kako ne bi otkrili tajne prolaze koji su vodili do grobne komore. To je pak većini arheologa neprihvatljivo jer bi se takvim skupnim pogubljenjima izbrisao velik broj žitelja.

Drugi slučaj u kojem su arheolozi demonstrirali svoju voljnost prihvaćanja Herodotovih tvrdnji je vezan za dvadesetogodišnje vremensko razdoblje gradnje piramide.

\subsection{Provjera teorija gradnje}

Japanci su se 1978. godine odlučili na sljedeći pothvat: podići piramidu visoku 18 metara pomoću metoda kojima su se navodno služili prvobitni graditelji piramida. U stvari su napravili ono što je trebalo učiniti puno ranije.

Tvrtka Nippon Corporation dobila je dozvolu egipatske vlade da na platou u Gizi, jugoistočno od Mikerinove piramide, sagradi mini-piramidu. Nisu smjeli upotrebljavati kamenje iz kompleksa u Gizi, a mini-piramida mogla je tamo ostati samo nekoliko dana nakon završetka gradnje. Nakon toga su je trebali potpuno srušiti i okolnom području vratiti prvobitan izgled.

Složivši se s postavljenim uvjetima, Japanci su se prihvatili vađenja kamenih blokova iz kamenoloma udaljenog oko $14 \mathrm{~km}$ i njihovog transporta do gradilišta. Blokove teške oko jedne tone nisu međutim uspjeli prevesti brodom preko Nila, to su učinili parobrodom; nisu ih mogli preko pješčane pustinje otpremiti do gradilišta, to su učinili helikopterom; grupe radnika pojedini blok nisu mogle podići više od pola metra, za to su se služili dizalicom.

Cijeli je projekt sniman, nakon čega je mini-piramida srušena. Pothvat što su ga poduzeli Japanci, pokazao je da su pretpostavke tradicionalnih istraživača o načinu gradnje vrlo upitne.

\section{Prve geodetske izmjere piramide}

\subsection{Talesova izmjera}

Vjeruje se da je grčki filozof, matematičar i astronom, Tales iz Mileta (624. - 547. pr. Kr.), bio prvi koji je točno izmjerio visinu piramide. Napravio je to pomoću užeta i njegove sjene, te je uveo i upotrijebio pojam omjera dužina. Problem koji se javlja kod ovakvog mjerenja visine piramide je taj što dužinu sjene treba mjeriti od središta baze piramide. Tales daje rješenje i za taj problem (slika 14). S pomicanjem sjene piramide pomiče se i linija koja povezuje vrh sjene sa središtem baze piramide. Kada ta linija 
bude paralelna sa osnovicom baze (na slici plave linije) dio sjene koji se nalazi unutar piramide bit će dug kao pola osnovice baze (stranica $a$ ). Vanjski dio se izmjeri i na taj način se izračuna koliko je visoka piramida (vidi [2]).

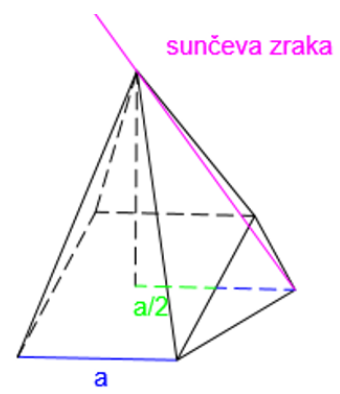

Slika 14: Prikaz Talesovog načina izmjere visine piramide (nacrtali autori)

\subsection{Rezultati izmjera triju velikih piramida}

Prve sustavne geodetske izmjere triju velikih gizaških piramida načinio je u drugoj polovici 19. stoljeća Sir Flinders Petrie (1853. - 1941.), glasoviti britanski arheolog i egiptolog te neumorni istraživač egipatskih starina, kojeg se drži “ocem egipatske arheologije”. Njegove izmjere, dane tablicom 1, upućuju da su im osnovice strogo kvadratna oblika te da su precizno orijentirane prema glavnim stranama svijeta. Premda se piramide razlikuju po osnovnim dimenzijama one imaju bliske proporcije koje, za svaku od njih, najbolje karakteriziraju veoma ujednačeni prikloni kutovi njihovih trokutnih bočnih ploha i prikloni kutovi bridova plašta prema osnovici $\left(\alpha_{0}\right.$ i $\left.\beta_{0}\right)$ (vidi sliku $15)$.

Tablica 1: Podaci prve izmjere provedene u drugoj polovici 19. stoljeća (Petrie)

\begin{tabular}{|c|c|c|}
\hline Strana & Duljina (m) & Kut otklona \\
\hline Sjeverna & 230.363 & $-3^{\prime} 20^{\prime \prime}$ \\
\hline Istočna & 230.320 & $-3^{\prime} 57^{\prime \prime}$ \\
\hline Južna & 230.365 & $-3^{\prime} 41^{\prime \prime}$ \\
\hline Zapadna & 230.342 & $-3^{\prime} 54^{\prime \prime}$ \\
\hline Prosjek & 230.348 & $-3^{\prime} 43^{\prime \prime}$ \\
\hline
\end{tabular}

Britanski topograf J. H. Cole (1891. - 1963.), utemeljitelj modernog sustava triangulacije, je početkom 20. stoljeća sa svojim geodetskim timom izvodio višegodišnja opsežna mjerenja kompleksa u Gizi i proveo račun izjednačenja pogrešaka rezultata mjerenja.

U radu Survey of Egypt, Paper No. 39 objavljenom 1925. godine u Kairu, iznijeo je podatke o:

- prvobitnoj duljini stranice osnovice $a_{0}$,

- prvobitnoj visini $h_{0}$,

- pripadnom priklonom kutu $\alpha_{0}$ bridova plašta prema osnovici, s pripadnim srednjim kvadratnim pogreškama za tri velike piramide.

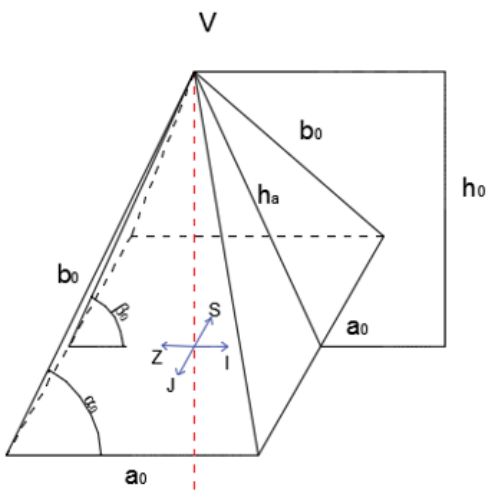

Slika 15: Prikaz svih stranica i kutova piramide koji su mjereni u geodetskim izmjerama (nacrtali autori)

S kojom zadivljujućom preciznošću je bila sagrađena Velika piramida na prethodno pomno poravnatom kamenitom platou najrječitije govore Coleovi podaci o izmjerenim vršnim kutovima njezine osnovice i njihovim malenim odstupanjima od pravoga kuta (tablica 3).

Podjednako su fascinantni i njegovi podaci o mjerenjima određenim prvobitnim duljinama, kutu otklona i ukupnom linearnom otklonu pojedinih stranica osnovice Velike piramide $\mathrm{u}$ odnosu na referentne geografske pravce sjeverjug $\mathrm{i}$ istok-zapad prema geografskim polovima određenim Zemljinom osi vrtnje (slika 8 i tablica 4 ).

Tablica 2: Procijenjene prvobitne dimenzije i pripadni prikloni kutovi bridova plašta triju velikih gizaških piramida (Cole)

\begin{tabular}{|c|c|c|c|}
\hline Naziv piramide & Prva ili Velika & Druga & Treća \\
\hline \hline Kralj graditelj & Keops & Kefren & Menkaura \\
\hline$a_{0}$ - stranica osnovice & $230,36 \pm 0,02 \mathrm{~m}$ & $215,26 \pm 0,04 \mathrm{~m}$ & $105,50 \pm 0,08 \mathrm{~m}$ \\
\hline$h_{0}$ - visina piramide & $146,72 \pm 0,18 \mathrm{~m}$ & $143,87 \pm 0,33 \mathrm{~m}$ & $65,55 \pm 0,05 \mathrm{~m}$ \\
\hline$h$ - današnja visina & $138,8 \mathrm{~m}$ & $136,4 \mathrm{~m}$ & $62,0 \mathrm{~m}$ \\
\hline$\alpha_{0}$ - prikloni kut plašta & $51^{\circ} 52^{\prime} 00^{\prime \prime} \pm 2^{\prime \prime}$ & $53^{\circ} 12^{\prime} 00^{\prime \prime} \pm 4^{\prime \prime}$ & $51^{\circ} 10^{\prime} 30^{\prime \prime} \pm 1 ' 20^{\prime \prime}$ \\
\hline$h_{0} / \alpha_{0}$ & 0,63692 & 0,66836 & 0,62133 \\
\hline$h_{0} / \alpha_{0}=1 / 2 \tan a_{0}$ & 0,63691 & 0,66836 & 0,62131 \\
\hline
\end{tabular}


Tablica 3: Podaci izmjere vršnih kutova osnovice Velike piramide

\begin{tabular}{|c|c|c|}
\hline Kut osnovice & Izmjereni kut & Odstupanje od 90 $^{\circ}$ \\
\hline \hline Sjeverozapadni & $89^{\circ} 59^{\prime} 58^{\prime \prime}$ & $-0^{\prime} 02^{\prime \prime}$ \\
\hline Jugozapadni & $90^{\circ} 00^{\prime} 33^{\prime \prime}$ & $+03^{\prime} 3$ \\
\hline Jugoistočni & $89^{\circ} 56^{\prime} 27^{\prime \prime}$ & $-3^{\prime} 33^{\prime \prime}$ \\
\hline Sjeveroistočni & $90^{\circ} 03^{\prime} 02^{\prime \prime}$ & $+3^{\prime} 02^{\prime \prime}$ \\
\hline
\end{tabular}

Ovi rezultati pokazuju da je osnovica Velike piramide, promatrana kao cjelina, neznatno zakrenuta u smjeru zapada, suprotno kazaljci na satu, za oko + 3' 06" (aritmetička sredina kuta otklona).

1984. godine bazu Velike piramide mjere američki arheolozi Mark Lehner (rođen 1950.) i David Goodman (rođen 1947.). Uz samu izmjeru napravljena je i geodetska mreža (mreža koja se određuje tako da se odrede fiksne točke s poznatim koordinatama te se sva mjerenja vrše pomoću tih točaka) koja je služila za izmjeru cijelog Gizaškog kompleksa. Za ishodište mreže odabrano je središte baze piramide kojemu su dodijeljene koordinate (N 100 000, E 500 000). Tim postupkom je onemogućen prikaz koordinata u negativnom iznosu. Kako bi izmjera bila olakšana Lehner i Goodman su tražili karakteristične točke na bazi piramide na koje će se njihova izmjera vezati te tako olakšati potrebna prekobrojna mjerenja da bi se dobila ocjena točnosti mjerenja. Primjer je karakteristična točka koja se nalazi u SI uglu, 115,802 metara sjeverno od središta Velike piramide i 115,607 metara istočno od istog. S obzirom na njihovu notaciju, koordinate navedene točke bi imale vrijednosti Northing 100 115,802 i Easting 500 115,607. Mreža se može koristiti za područje koje se pruža u krugu od 100 kilometara oko Velike piramide.
Nakon što se izvrši pretvorba u koordinate geodetske mreže sa ishodištem u središtu Velike piramide može se upotrijebiti metoda linearne regresije $e^{5}$ na podatke dobivene Lehner/Goodman izmjerom. To je zbog oštećenja nekih rubnih dijelova baze Velike piramide a naročito njene sjeverne strane pogodno za određivanje koordinata vrhova baze. Koristeći uz to i geometriju četverokuta i s obzirom na točnost mjerenja, pogreška koje se može javiti pri određivanju koordinata SI ugla iznosi $16 \times 9$ centimetara. Ako se ova pogreška želi svesti na minimum onda se treba pretpostaviti, kao što su raniji učinili Petrie i Cole, da je sjeverna strana paralelna južnoj te da je mjesto sjecišta dijagonale sa osnovicom pravo mjesto gdje se nalazio vrh baze. Rezultati Lehner/Goodman izmjere nakon primjene opisanog postupka na sve rubove baze Velike piramide prikazani su u tablici 5.

Tablica 5: Prikaz rubova baze Velike piramide uz pomoć koordinate izvedenih iz mreže čije je ishodište smješteno u središte baze s koordinatama ( $N$ 100 000, E 500 000)

\begin{tabular}{|c|c|c|c|}
\hline Ugao & Northing & Easting & Pogreška (m) \\
\hline \hline SI & 100115.288 & 500115.034 & \pm .054 \\
\hline JI & 99885.006 & 500115.262 & \pm .093 \\
\hline JZ & 99884.759 & 499884.954 & \pm .060 \\
\hline SZ & 100115.095 & 499884.645 & \pm .050 \\
\hline
\end{tabular}

Pomoću ovih podataka mogu se izračunati duljine stranice i pripadajući kutovi.

U tablicama 6 i 7 dana je usporedba Petrie-ove, Cole-ove i Lehner/Goodman-ove izmjere stranica i pripadnih kutova.

Tablica 4: Podaci izmjere stranica osnovice Velike piramide i njihova otklona (znak “+” ispred kuta otklona ističe da se radi o pozitivnim smjeru vrtnje)

\begin{tabular}{|c|c|c|c|c|}
\hline Stranica osnovice & Duljina $a_{0}$ & Najveća pogreška na krajevima & Kut otklona $\Delta f$ & Otklon stranice $a_{0} \times \Delta f$ \\
\hline \hline S - sjeverna & $230,253 \mathrm{~m}$ & $6 \mathrm{~mm}$ na oba kraja & $+2 ' 30 ”$ & $0,168 \mathrm{~m}$ \\
\hline I - istočna & $230,391 \mathrm{~m}$ & $6 \mathrm{~mm}$ na oba kraja & $+1 ' 57 ’$ & $0,131 \mathrm{~m}$ \\
\hline J - južna & $230,454 \mathrm{~m}$ & $10 \mathrm{~mm}$ Z i $30 \mathrm{~mm}$ I & $+5 ’ 30 ”$ & $0,369 \mathrm{~m}$ \\
\hline Z - zapadna & $230,357 \mathrm{~m}$ & $30 \mathrm{~mm}$ na oba kraja & $+2 ’ 28 ”$ & $0,165 \mathrm{~m}$ \\
\hline
\end{tabular}

${ }^{5}$ Postupak uklapanja funkcije (pravca, kojeg nazivamo pravcem regresije) u skup točaka koje predstavljaju određene podatke. Ta funkcija može služiti kao matematički model tih podataka i možda neće prolaziti ni kroz jednu točku, ali modelira podatke tako da u izvjesnom smislu njihova međusobna udaljenost bude sto manja. Ovakva metoda obrade eksperimentalnih podataka poznata je pod nazivom metoda najmanjih kvadrata.

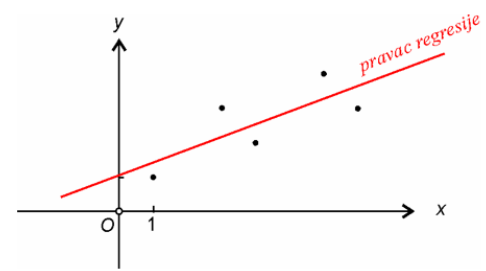


Tablica 6: Prikaz rezultata svih izmjera stranica:

\begin{tabular}{|c|c|c|c|c|c|c|}
\hline Strana & $\leftarrow$ & Lehner/Goodman & $\rightarrow$ & Petrie & Cole & Dorner \\
\hline \hline & Min & Mean & Max & & & \\
\hline Sjever & 230.286 & 230.389 & 230.493 & 230.363 & 230.253 & 230.328 \\
\hline Istok & 230.135 & 230.282 & 230.429 & 230.320 & 230.391 & 230.369 \\
\hline Jug & 230.155 & 230.309 & 230.462 & 230.365 & 230.454 & 230.372 \\
\hline Zapad & 230.227 & 230.337 & 230.447 & 230.342 & 230.357 & 230.372 \\
\hline Prosjek & & 230.329 & & 230.348 & 230.364 & 230.360 \\
\hline
\end{tabular}

Tablica 7: Prikaz rezultata izmjere odstupanja kutova od 90:

\begin{tabular}{|c|c|c|c|c|c|c|}
\hline Strana & $\leftarrow$ & Lehner/Goodman & $\rightarrow$ & Petrie & Cole & Dorner \\
\hline & Min & Mean & Max & & & \\
\hline Sjever & $-1^{\prime} 19^{\prime \prime}$ & $-2^{\prime} 52^{\prime \prime}$ & $-4^{\prime} 25^{\prime \prime}$ & $-3^{\prime} 20^{\prime \prime}$ & -2 ' $28^{\prime \prime}$ & $-2^{\prime} 28^{\prime \prime}$ \\
\hline Istok & $-1^{\prime} 12^{\prime \prime}$ & $3^{\prime} 24^{\prime \prime}$ & $-5^{\prime} 36^{\prime \prime}$ & $-3^{\prime} 57^{\prime \prime}$ & $-5^{\prime} 30^{\prime \prime}$ & $-3^{\prime} 26^{\prime \prime}$ \\
\hline Jug & $-1^{\prime} 24^{\prime \prime}$ & $-3^{\prime} 41^{\prime \prime}$ & $-5^{\prime} 58^{\prime \prime}$ & $-3^{\prime} 41^{\prime \prime}$ & -1'57' & -2 '31" \\
\hline Zapad & $-2^{\prime} 58^{\prime \prime}$ & $-4^{\prime} 37^{\prime \prime}$ & -6' & $-3^{\prime} 54^{\prime \prime}$ & $-2^{\prime} 30^{\prime \prime}$ & $-2^{\prime} 47^{\prime \prime}$ \\
\hline Prosjek & & $-3^{\prime} 38^{\prime \prime}$ & & $-3^{\prime} 43^{\prime \prime}$ & -3'06" & $-2^{\prime} 48^{\prime \prime}$ \\
\hline
\end{tabular}

\section{Pokazuju li piramide kontinentalni pomak?}

Provedene geodetske izmjere potrebno je povezati sa geologijom, znanošću koja se bavi proučavanjem Zemlje, koja pokušava objasniti kako je Zemlja oblikovana i kako se mijenja. Geolozi stoga mogu dati odgovor na pitanje može li kontinentalni pomak i tektonika ploča uzrokovati promjene na Platou u Gizi te jesu li oni uzroci odstupanja u orijentaciji Piramide?

Sa instrumentima i oruđem koje su imali na raspolaganju, stari su astronomi, geodeti i graditelji Velike piramide postigli točnost od 3.4 lučnih minuta prema sjeveru. Nakon 4000 godina astronomi s akademije Academie Royale su uspjeli odrediti način na koji će orijentirati opservatorij $\mathrm{u}$ Parizu 1667. godine, te su ga i prenijeli u prirodu tako da je taj opservatorij orijentiran s točnošću od 6 lučnih minuta, što je skoro dvostruko odstupanje od onog koje su postigli stari Egipaćani. Smatra se da je Velika piramida orijentirana savršeno točno te da je danas njezina minorno narušena orijentacija uzrokovana kontinentalnim pomakom i tektonikom ploča.

U nastavku će biti navedeni geološki procesi koji se zbivaju u prirodi i koji su mogli doprinijeti narušavanju orijentacije i promjene nagiba platoa na kojem se nalaze Egipatske piramide:

\section{Tektonika ploča}

2. Podizanje razine Sredozemnog mora

3. Potresi

4. Plimni valovi

\section{Vulkanske erupcije}

6. Gibanje Zemaljskog pola

Međutim, zbog položaja Platoa prema Sredozemnom moru, zapisa o posljedicama potresa, ne postojanju vulkana na području Egipta, pomaka geografskih koordinata uzrokovanih gibanjem Zemaljskog pola koji iznosi 31,1 lučnu sekundu kroz 4500 godina što je premalo da bi se uzelo u obzir, znanstvenici odbacuju pojave (2), (3), (4), (5) i (6).

Kontinentalni pomaci i praćenje tektonike ploče je vrlo kompliciran i zahtjevan zadatak. Objašnjenje tih procesa i razne teorije preopširne su da budu objašnjene u ovom radu. S tim u vezi navest ćemo samo neke rezultate vezane za mogući pomak sjeveroistočnog dijela Afričke ploče na mjestu gdje se dotiče sa Euroazijskom i Arapskom pločom, područja na kojem se nalazi Velika piramida.

Pomak tektonskih ploča za određenu točku na zemljinoj površini određuje se uz pomoć raznih metoda geodetskih mjerenja. Najčešce se upotrebljavaju: Satelite Laser Rangig (SLR), Very Long Basiline Interferometry (VLBI) i Global Position System (GPS), tj. globalni navigacijski satelitski sustavi (GNSS). Pretpostavlja se da je kretanje tektonskih ploča pravilno i predvidivo, osim na području gdje se javljaju česti potresi i vulkanske erupcije koje uzrokuju neravnomjeran pomak ploča u određenom periodu, što ovdje nije slučaj.

Razna mjerenja su obavljana od strane američkih istraživača koji su uz pomoć GPS tehnologije promatrali pomake na području Egipta u razdoblju od 1994. do 1997. S obzirom na brzinu gibanja Afričke ploče od $5-6 \pm 2 \mathrm{~mm} /$ god., došli su do zaključka da pomak Platoa 
tijekom 4500 godina nema skoro nikakav značaj na horizontalni i vertikalni pomak piramide.

Rotacija Afričke ploče bi mogla imati puno veći utjecaj na orijentaciju piramide. Ako se računa rotacija ploče pomoću HS2 - NUVEL 1 modela za traženo područje dobiva se rotacija od 58.32" odnosno $0.0162^{\circ}$ u smjeru istokzapad u periodu od 4500 godina. Ako se ovi rezultati primijene na sadašnji položaj Velike piramide oni skoro pa neće imati nikakav utjecaj. To znači da je Velika piramide izgrađena sa malim odmakom od idealne orijentacije u prostoru ili da je izgrađena puno ranije nego što mnogo raznih egiptologa $\mathrm{i}$ istraživača tvrdi.

Ako se pretpostavi da se Afrička ploča rotira jednolikom brzinom i ako se pretpostavi da je Velika piramida bila savršeno točno orijentirana u prostoru kada je izgrađena, onda se pomoću ovih podataka dolazi do zaključka da je piramida sagrađena prije 24700 godina.

\section{Analiza unutrašnje strukture}

Ulaz u Piramidu nalazi se na sjevernoj strani, nešto više od 17 metara iznad površine zemlje i 7 metara od sredine osnovice baze. Smješten je u devetnaestom od ukupno 203 reda, koliko ih Piramida danas ima. Ulaz prelazi u silazni hodnik pod kutom od $26^{\circ} 28^{\prime} 24$ ". Silazni hodnik visok je oko 1,20 metara i širok metar, a njime se prelazi udaljenost nešto veća od 104 metra. Otprilike prva njegova četvrtina prolazi kroz Piramidu, dok je ostatak oko $78 \mathrm{~m}$ probijen kroz čvrstu stijenu po kojoj Piramida počiva. Silazni hodnik nakon toga ide vodoravno nekih $9 \mathrm{~m}$, te na kraju ulazi u podzemnu dvoranu. Podzemna dvorana nalazi se otprilike $30 \mathrm{~m}$ ispod površine zemlje, odnosno osnovice Piramide, a po površini je veća od svih ostalih. Dugačka je oko $8 \mathrm{~m}$, široka $14 \mathrm{~m}$, a visoka nešto više od $4 \mathrm{~m}$. Ulaz u dvoranu je u donjem istočnom uglu sjevernog zida.

Najpopularnija hipoteza o namjeni podzemne dvorane kaže da je ona prvobitno trebala poslužiti kao pogrebna komora. Međutim, izgleda da su arhitekti od toga odustali, primjerice zbog neizdrživih fizičkih uvjeta i nedostatka zraka na mjestu na kojemu je trebalo iskopati potreban niz dvorana, kao i zbog moguće opasnosti od poplave. Dvorane i hodnici napravljeni su u samom tijelu Piramide, na različitim razinama. To bi moglo objasniti nedovršeni izgled podzemnog kompleksa kao i namjera da se moguće pljačkaše navede na krivi zaključak da unutrašnjost piramide nikada nije dovršena i da ih se odvrati o potrage za blagom.

Smatra se da je s istom svrhom ulaz u uzlazni hodnik sakriven u stropu silaznog hodnika, tridesetak metara od ulaza u Piramidu. Kut nagiba uzlaznog hodnika identičan je kutu silaznog i iznosi $26^{\circ} 28^{\prime} 24$ ". Uzlazni hodnik sastoji se od dva dijela, jedan dužine $18 \mathrm{~m}$ a drugi, širine oko $1 \mathrm{~m}$ i visine $1.1 \mathrm{~m}, 33.5 \mathrm{~m}$ i završava raskrižjem.

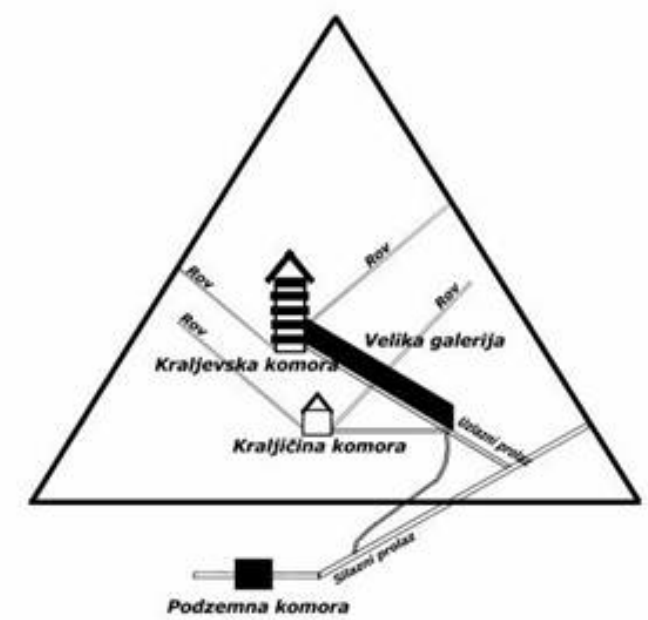

Slika 16: Prikaz presjeka Velike piramide (Izvor: [26])

$\mathrm{Na}$ raskrižju započinje vodoravni hodnik dugačak $40 \mathrm{~m} \mathrm{i}$ širok oko $1 \mathrm{~m}$, koji završava na dnu istočnog kuta sjevernog zida Kraljičine dvorane, dugačke gotovo $6 \mathrm{~m}$ i malo šire od $5 \mathrm{~m}$. Ta se dvorana nalazi točno ispod vrha Piramide, u ravnini s dvadeset i petim redom. Strop dvorane napravljen je od kosih blokova, čiji kut nagiba iznosi oko $30^{\circ} 30^{\prime}$. Ukupna visina od poda do vrha krovnog zabata Kraljičine dvorane je nešto više od $6 \mathrm{~m}$.

Jedna od zanimljivosti Kraljičine dvorane su dva kanala, pretpostavlja se za zrak, jedan u sjevernom i drugi u južnom zidu. Isklesani su u kamenim blokovima i naglo završavaju, ostavljajući još $12 \mathrm{~cm}$ zida. Kanali su pravokutnog oblika sa stranicama dugačkim $21.5 \mathrm{~cm} \times 20 \mathrm{~cm}$.

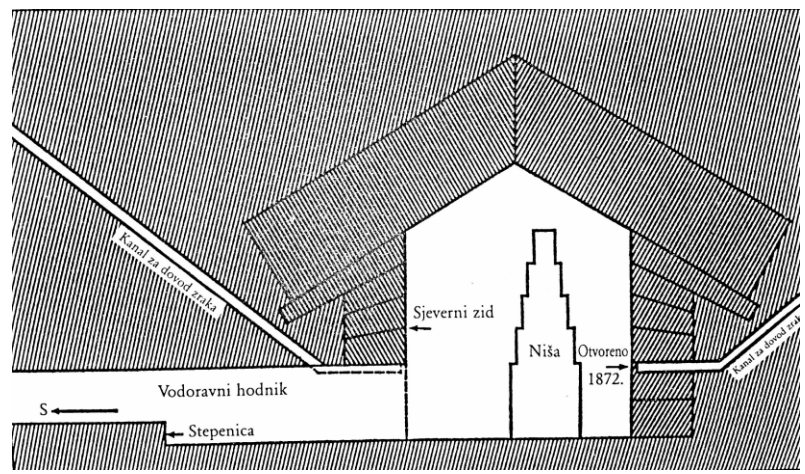

Slika 17: Prikaz presjeka Kraljičine dvorane (Izvor: [14])

$\mathrm{Na}$ izlazu iz vodoravnog hodnika počinje se protezati velika galerija koja je za razliku od drugih hodnika visoka 8.6 metara te 46.68 metara duga. Ona vodi do kraljeve odaje. Kraljeva odaja, kao najviša od postojećih triju, s visinom od $5.85 \mathrm{~m}$, proteže se $10.47 \mathrm{~m}$ od istoka prema zapadu te $5.23 \mathrm{~m} \mathrm{u}$ smjeru sjever-jug. Na visini od jednog metra nalaze se dva okna koja vode prema vanjskim stranama piramide, njihova svrha je prema vjerovanjima Starih Egipćana 
je putokaz prema zvijezdama koji olakšava odlazak u drugi svijet. Strop u kraljevoj odaji posebno je ojačan koso postavljenim kamenim pločama radi velike težine piramide. Tako ojačan strop daje sigurnost Kraljevoj odaji i smanjuje mogućnost savijanja. U kraljevoj odaji pronađen je sarkofag koji po vjerovanjima pripada vladaru Keopsu.

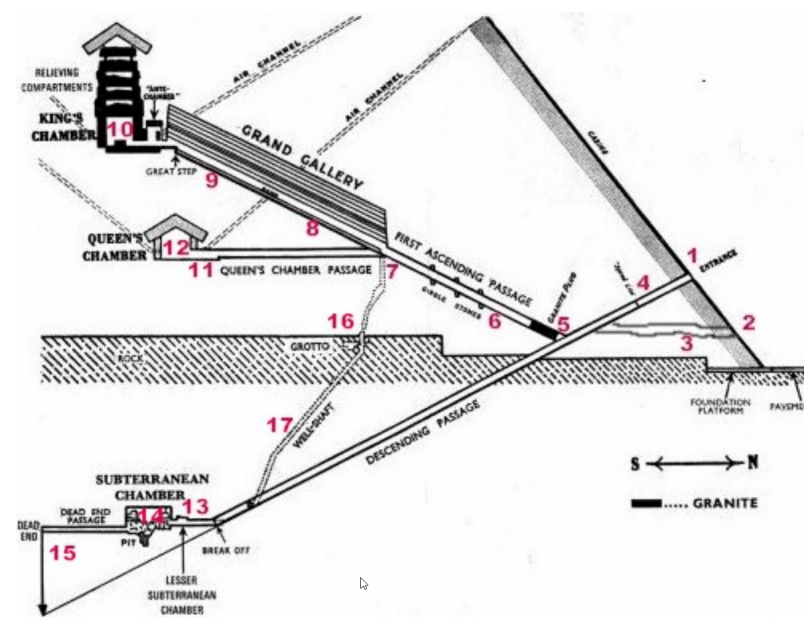

Slika 18: Prikaz otvora Kraljičine dvorane (odaje) koje je otkrio Rudolf Gantenbrik (Izvor: [23])

\section{Svrha gradnje piramide; od enciklopedije izgubljenog znanja do elektrane}

Proučavajući literaturu o starom Egiptu ([1], [4], [11]), nailazi se na mnogo različitih tumačenja svrhe gradnje piramida. Svoje su ideje branili stručnjaci raznih područja, pisci, ali i mistici i vidovnjaci. Oni ovdje neće biti ponaimenice navedeni, već će biti iznesene neke od njihovih ideja.

Osim uobičajenog stava egiptologa, prema nekim autora piramide su podignute prije više od 10000 godina te nisu izgrađene kao grobnice nego kao spremišta povijesti čovječanstva od samog početka pa sve do danas; povijest je zapisana jezikom matematike, geometrije i astronomije, a Velika piramida predstavlja kroniku prošlosti, sadašnjosti i budućnosti.

Zagovornici hipoteze da Egipćani nisu podigli Veliku piramidu to pak potkrepljuju činjenicom da su unutarnji zidovi bez natpisa, slika i drugog simbolizma obično povezanog s fino izrađenom kraljevskom dekoracijom.

Zamisao da su drevni Egipćani imali nekakvu vrstu električne rasvjete, povezana je sa zagonetkom kako su ljudi duboko u podzemlju mogli oslikavati zidove bez baklji, bez da je ostalo tragova čađe. Objašnjenje da su koristili komplicirani sustav ogledala mnogi uzimaju za neostvarljivo. Više o pretpostavci da je Kraljeva odaja bila srce elektrane u Gizi i razna objašnjenja s tim u vezi mogu se naći na primjer u knjizi Christofera Dunna: The Giza Power Plant [21].

\section{Konstante povezane s piramidom}

\subsection{Veza $s$ astronomijom}

Do kraja 19. stoljeća sakupila se velika i zanimljiva zbirka povezanosti raznih izmjera piramida s astronomijom. Smatramo da te poveznice mogu biti prilično subjektivne jer svaka veličina u prirodi može biti prikazana na puno raznih načina iz kojih se mogu izvući fascinantni zaključci. Bez obzira na našu sumnju u objektivnost pri takvom zaključivanju mišljenja smo da se u radu o Velikoj piramidi uspostavljene veze ne smije zaobići.

Slijedi prikaz dijela podataka koji se mogu pronaći u literaturi ([1], [14], [22]):

1. Dužina stranice osnovice koja iznosi 9131 palac (palac $-2,54 \mathrm{~cm}$ ) podijeljena s jednim laktom (25 palaca) iznosi 365.24, što je broj dana u solarnoj godini.

2. Opseg kruga čiji je promjer dužina predvorja kraljeve odaje (116.25 palaca) iznosi 365.24 palca.

3. Širina Kraljeve dvorane (206.066 palaca) pomnožena s kvadratnim korijenom broja $\pi$ iznosi 365.24 palca.

4. Dvostruka dužina Kraljeve dvorane (412.12 palaca) izmjerena na podu Velike galerije od te se udaljenosti vertikalno uzdiže 365.24 palca.

5. Zbroj svih stranica osnovice jednak je broju dana u stoljeću.

6. Ukupan broj palaca svih stranica trideset i petog reda jednak je broju dana u 80 solarnih godina.

7. Dvostruka dužina osnovice $(2 \times 9131.26$ palaca $)$ jednaka je broju godina u precesiji ekvinocija i, osim toga, ukupnom broju palaca svih stranica pedesetog reda;

8. Zbroj dužine i visine Kraljeve dvorane podijeljen s njezinom dužinom jednak je broju $\pi$.

9. Zbroj dužine i širine sarkofaga pronađenog u Kraljevoj odaji, podijeljen s njegovom visinom jednak je broju $\pi$.

10. Velika piramida je savršeni kalendar koji pokazuje godišnja doba i funkcionira poput ogromnog Sunčevog sata čija sjena, između ostalog, označava solsticije i trajanje godine. 
11. Ako označimo da je osnovica baze piramide ekvivalentna ekvatoru tada se u vrhu piramide nalazi središte mjeseca koji je smješten na površini Zemlje (slika 19).

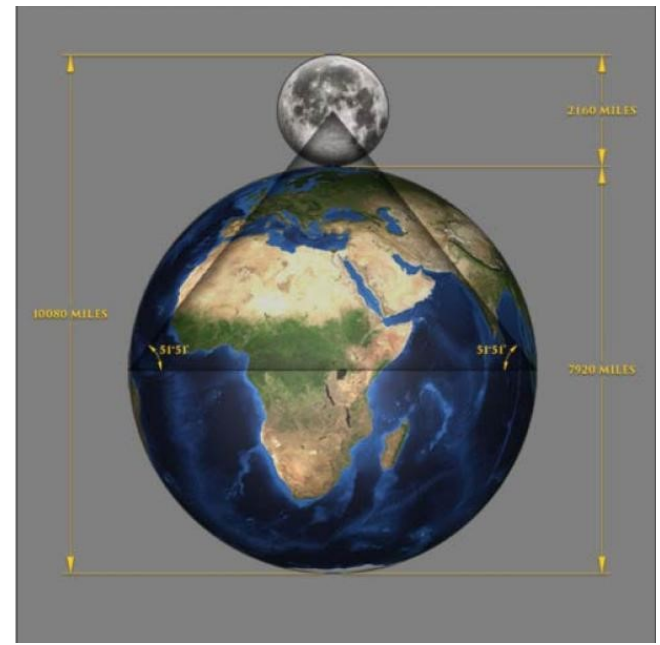

Slika 19: Prikaz piramide kao spojnice Zemlje i Mjeseca (Izvor: [19])

\subsection{Zlatni broj Fi $(\varphi)$ i broj Pi $(\pi)$}

\subsubsection{O zlatnom rezu i Fibonaccijevim brojevima}

Zlatni rez, koji se još naziva zlatna sredina, božanski ili zlatni omjer je matematičko-strukturalna konstanta koja se najčešce veže za umjetnost. Smatra se jednom od temeljnih konstanta matematike, čiju nam važnost opisuje i citat slavnog njemačkog znanstvenika Johannesa Keplera: “Geometrija posjeduje dva blaga: jedno je Pitagorin teorem, a drugo zlatni rez. Prvo se može usporediti s čistim zlatom, a drugo s draguljem neprocjenjive vrijednosti."

Geometrijski, Zlatni rez je način podjele neke mjerljive veličine, na primjer odsječka $A C$, tako da omjer između većeg i manjeg dijela bude jednak omjeru izmedu njihova zbroja i većeg (slika 20).

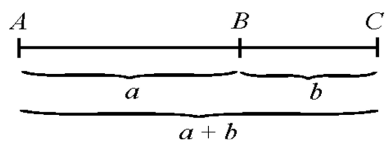

Slika 20: Prikaz Zlatnog reza

Ako je $B$ točka koja u omjeru zlatnog reza dijeli $A C$ i ako je $A B=a, B C=b$ onda je po definiciji

$\frac{a}{b}=\frac{a+b}{a}$.

Sređujući (1) dobivamo $a^{2}=a b+b^{2}$, odakle dijeljenjem $\mathrm{s}$ $b^{2}$ slijedi

$\left(\frac{a}{b}\right)^{2}-\frac{a}{b}-1=0$ tj.

$x^{2}-x-1=0$.

Nepoznanica $x=\frac{a}{b}$ iznosi $\frac{1+\sqrt{5}}{2}=1,6180 \ldots$ za pozitivan, odnosno $\frac{1-\sqrt{5}}{2}=-0,6180 \ldots$ za negativan korijen. Osim toga, rješenja su do na predznak recipročna: $0,6180 \ldots=$ $\frac{1}{1,6180 \ldots}$.

Omjer zlatnog reza obično se simbolički označava grčkim slovom $\varphi$. Tako je

$\varphi^{2}-\varphi-1=0 \quad$ ili $\quad \varphi^{2}=\varphi+1$.

Množenjem obje strane proizvoljan broj puta s $\varphi$ dobije se

$\varphi^{n}=\varphi^{n-1}+\varphi^{n-2}$

što zlatni rez povezuje s nizom Fibonaccijevih brojeva.

U matematici, Fibonaccijevi brojevi oblikuju niz definiran rekurzivnom funkcijom (funkcija kojoj se definirajuća funkcija primjenjuje unutar definicije):

$F(n):=\left\{\begin{array}{lll}0 & \text { ako je } & n=0 \\ 1 & \text { ako je } & n=1 \\ F(n-1)+F(n-2) & \text { ako je } & n>1\end{array}\right.$

Dakle, nakon prve početne vrijednosti, svaki sljedeći broj je zbroj dvaju prethodnika. Dobivamo tako redom

$$
0,1,1,2,3,5,8,13,21,34,55,89,144, \ldots
$$

Lako je sada uočiti da se svojstvo (3) koje generira geometrijski niz

$1, \varphi, \varphi^{2}, \ldots, \varphi^{n}, \ldots$

nalazi i u Fibonaccijevom nizu (5), za $n>0$. Naime, količnik svakog člana niza (5) i njemu prethodnog člana teži veoma brzo ka $\varphi$. Vrijednosti osciliraju oko idealne veličine:

$\frac{3}{2}<\frac{8}{5}<\frac{21}{13}<\ldots<\varphi<\ldots<\frac{34}{21}<\frac{13}{8}<\frac{5}{3}$.

Koliko je brzo asimptotski dostižu najbolje se vidi iz

$\frac{55}{34}=1,6176 \ldots<\varphi<\frac{89}{55}=1,6181 \ldots$ 


\subsubsection{Ludolfova konstanta $\pi$}

Arhimedova $^{6}$ ili Ludolfova ${ }^{7}$ konstanta $\pi$ (pi) najčešća je konstanta koja se javlja u matematici i prirodnim znanostima. Od njenih mnogobrojnih definicija izdvajamo sljedeću: $\pi$ je omjer opsega kruga i njegovog promjera.

Broj $\pi$ je iracionalan broj, što znači da se ne može prikazati u obliku razlomka čiji je brojnik cijeli, a nazivnik prirodni broj. Njegov decimalni prikaz je stoga beskonačan $\mathrm{i}$ neperiodičan:

$$
\pi=3,14159265358979 \ldots
$$

Danas, uz pomoć računala, broj točno izračunatih decimala vrtoglavo raste. Na primjer, 2013. godine je broj točnih znamenaka iznosio dvanaest tisuća milijardi. Ipak, sve do pojave računala su pokušaji izračuna broja $\pi$ davali aproksimacije koje su relativno sporo konvergirale prema točnom decimalnom prikazu.

Tako se prvi pokušaji javljaju u starom Egiptu; zabilježeno je da se u 17. st. pr. Kr. za spomenuti omjer rabio broj 3,16049. Njegova pogreška točnosti je unutar $1 \%$ i vrlo je mala za dostupne alate računa tog doba. Sljedeću bolju aproksimaciju osmislio je Arhimed oko 280. godine pr. Kr. Upisivao je i opisivao poligone unutar i izvan jedinične kružnice, čime je dobio, iako grubu, donju i gornju granicu za površinu kruga. Iz toga je zaključio sljedeće:

$\frac{223}{71}<\pi<\frac{22}{7}, \quad$ tj. $3,1408<\pi<3,1429$.

Točnost na 2 decimale postiže se tek za $n=96$, dok je $n=1000$ potrebno za 3 . Veći skok u izračunu broja decimala zabilježen je krajem šesnaestog stoljeća: Ludolph van Ceulen je izračunao $\pi$ na 35 decimala, a potom $u$ osamnaestom stoljeću: William Hanks, 707 decimala. Kao zanimljivost navedimo da je samo prvih 528 od 707 znamenaka točno.

Od 1988. broj $\pi$ ima i svoj dan, 14. ožujka (3.14 u engleskoj notaciji).

Više o zlatnom rezu i općenito o matematičkim konstantama može ne naći npr. u [3], [6], [12].

\subsection{Pi i Fi u izmjerama}

John Taylor (1781. - 1864.) je bio engleski izdavač, esejist i pisac. U knjizi The great pyramid; why was it built \& who built it? (1859.), Taylor tvrdi da su broj $\pi$ i zlatni rez namjerno uključeni u dizajn Velike piramide u Gizi. On je do svojih zaključaka došao temeljem analize jednog Herodotovog knjiškog zapisa.

Njegove teorije je zatim proširio Charles Piazzi Smyth (1819. - 1900.), talijansko-škotski astronom poznat po

\footnotetext{
${ }^{6}$ Arhimed (3 st. pr. Kr.), grčki matematičar, fizičar i astrolog

${ }^{7}$ Ludolph van Ceulen (1540. - 1610.), njemački matematičar
}

mnogim inovacijama $u$ astronomiji i po svojim mjeriteljskim studijama.

Prva teorija Johna Taylora vezana uz mjere Velike piramide glasila je da je njezina ukupna visina jednaka dvostrukoj dužini osnovice, pa je nagađao da se to nalazi u izravnoj vezi s odnosom dijametra prema obujmu kruga. U oba slučaja dobiva se broj 3,141592... Ta se vrijednost može objasniti i na drugi način - da se visina piramide prema dvostrukoj dužini osnovice odnosi kao 1 naprama $3,14159 \ldots$

Na temelju ove pretpostavke Taylor je dobio kut nagiba od $51^{\circ} 51$ ' 14.3 " koji se obično naziva $\pi$ kutom ili idealnim kutom. Usporedbom idealnog priklonog kuta plašta Velike piramide sa srednjom vrijednošću određenom Coleovim izmjerama (Tablica 1) očita je gotovo savršena podudarnost. Razlika među njima je u tehničkom smislu beznačajna i iznosi neznatne 2' 22", što uvjerljivo govori koliko su tijekom njezine gradnje bili pedantno vođeni prikloni kutovi ploha i bridova prema zadanoj geometrijskoj proporciji. Pokazalo se da vrijednost broja $\pi$ postoji samo kod Velike piramide i nije pronađena niti kod jedna druge piramide u Egiptu.

Niz pitanja javlja se oko značenja spomenute vrijednosti broja $\pi$. Pojavljuje li se ona slučajno ili ne? Je li on ili ona izrazio/la svoju mudrost i poznavanje broja $\pi$ uključivši ga u geometriju Piramide? Ako se broj $\pi$ pojavljuje tek slučajno ili kao izračunata konstanta tada ne bi trebali očekivati da će se on ponovno pojaviti kod bilo koje druge dimenzije Velike piramide. Međutim, to je uistinu potvrđeno, ne jednom već mnogo puta.

Jedan od takvih slučajeva odnosi se na izračunavanje volumena granitnog vratnog krila koje se nalazi u predvorju Kraljeve dvorane. Visina od 48.57 palaca $(1.23 \mathrm{~m})$ puta debljina od 15.7 palaca $(0.40 \mathrm{~m})$ puta širina od 41.2 palca $(1.05 \mathrm{~m})$ podjeljeno s 10000 daje broj od 3.1417 što je približno jednako broju $\pi$. U ovom slučaju su ostavljeni palci budući da se kod prenošenja u metrični sustav ne dobivaju iste vrijednosti, a mjerne jedinice starih Egipćana nisu bile izvedene iz metričnog nego iz "prirodnog” sustava (lakat, palac, stopa itd...).

Za drugu potvrdu pojave broja $\pi$ zaslužan je Piazzi Smyth. On ga je izveo iz visine trideset i petog reda Piramide podijeljene s desetinom vodoravne udaljenosti od te točke do vertikalne osi. Do tog je proračuna došao promatranjem debljine građevnog kamenja. Piramida je građena vodoravnim nizovima kvadratnih kamenih blokova čija debljina kod osnovice iznosi oko $1.27 \mathrm{~m}$. Kako se Piramida, niz po niz, uzdiže u visinu, debljina kamenih blokova smanjuje se do $0.68 \mathrm{~m}$ u trideset petom redu. Tada, u trideset i šestom redu, dolazi do iznenadnog povratka na debljinu od $1.27 \mathrm{~m}$, koja uglavnom ostaje takva u preostalim redovima. Zbog 
toga je Smyth procijenio da je tridest i peti red vrlo znakovit te je, izmjerivši vodoravnu udaljenost od njega do središnje osi Piramide, otkrio da ona iznosi 3652.42 stope ili broj dana u godini pomnožen s deset.

Osim broja $\pi$ u Veliku piramidu je uključen i broj Fi $(\varphi)$, tj. zlatni broj. Zabilježeno je da su svećenici iz Egipatkog hrama Herodotu rekli da je Velika piramida oblikovana tako da površina bilo koje strane bude jednaka kvadratu visine. Matematičari su pojednostavili odnose u Velikoj piramidi jednostavno ju povezavši s pravokutnim trokutom čija osnovica ima jediničnu dužinu jedan, visina kvadratni korijen od $\varphi$, a hipotenuza $\varphi$ (slika 21).

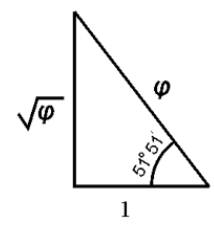

Slika 21: Prikaz pravokutnog trokuta s $\pi$ kutom čija osnovica ima jediničnu dužinu (nacrtali autori)

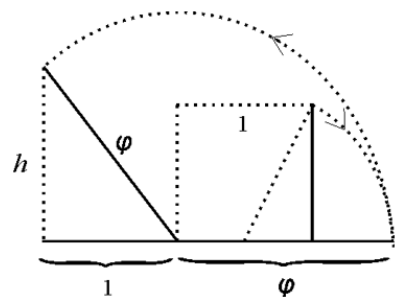

Slika 22: Geometrijska konstrukcija zlatnog reza $i$ veza $s$ visinom $h$ velike piramide (nacrtali autori)

Većina egiptologa je složna oko tvrdnje da su Egipćani u potpunosti razumjeli trigonometrijska svojstva Pitagorinog trokuta, te da su proporcije Velike piramide određene vrijednostima brojeva $\pi$ i $\varphi$. Oni isto tako tvrde da su brojni umjetnički prikazi oblikovani i izvedeni uz namjerno uključivanje tih brojeva, te i dalje aktivno tragaju za drugim mogućim odnosima.

Na primjer, da je visina Velike piramide pomnožena s $10^{9}$ jednaka točnoj udaljenosti Zemlje od Sunca, često je ponavljana i pisana tvrdnja. Međutim, iz samog izričaja ove tvrdnje jasno je da ona ne vrijedi. Dokaz tome je što Zemlja oko Sunca putuje po eliptičnoj putanji tako da ova vrijednost može biti prosječna ili srednja udaljenost. Zato bi, da bude točna, spomenuta tvrdnja trebala glasiti ovako: Visina Velike piramide pomnožena s $10^{9}$ i pretovrena u milje jednaka je prosječnoj srednjoj udaljenosti Zemlje od Sunca. Ova zanimljiva veza također je potvrđena i kod drugih izmjera Velike piramide. Neki autori navode da se ta udaljenost točnije dobiva iz nacrta osnovice prije nego iz visine Velike piramide. Smyth kaže da se spomenuta vrijednost također može dobiti ili tako da se visina trdeset i petog reda kamenih blokova pomnoži s 10 ili tako da se dužina predvorja pomnoži s 100 .

Kamen smutnje pri određivanju mjera Velike piramide su i piramidni (sveti) lakat i piramidni palac. Profesor Smyth potaknuo je uvođenje piramidnog lakta i piramidnog palca kao standardne jednice u mjernom sustavu Velike piramide. Ustanovio je da je 999 piramidnih palaca jednako 1000 standrardnih palaca. Na isti je način izračunao da je mjerna jedinica upotrijebljena pri oblikovanju i izgradnji Velike piramide bila lakat koji ima 25 piramidnih palaca. Kod navođenja mjera iz praktičnih je razloga najbolje uzeti da Piramidni palac odgovara standardnom.

\section{Izrada 3D modela piramide}

U sklopu izrade diplomskog rada [5], autor je izradio 3D model piramide koji je poslužio kao stvarno predočenje građevine u mjerilu kako bi se dobio dojam o odnosu duljine stranica i visine piramide.

Model piramide je u mjerilu 1: 1150 zbog nemogućnosti printanja stranice veće od $20 \mathrm{~cm}$ (slika 23).

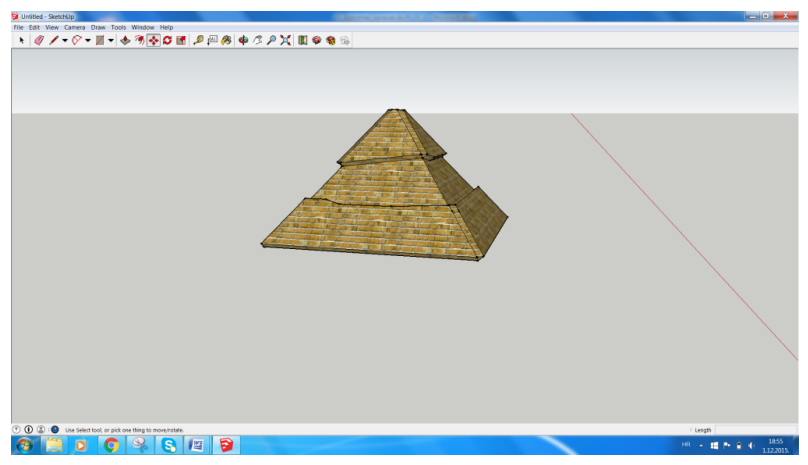

Slika 23: Prikaz konačnog oblika piramide (Modelirano upotrebom programa SketchUp 2015)

\section{Zaključak}

Keopsova piramida jedna je od najvećih misterija svijeta koju znanstvenici pokušavaju riješiti već više od 2000 godina. Mnogi tvrde da znaju što predstavlja ta monumentalna građevina te na koji je način građena. Fascinantna je činjenica koja govori kako je Velika piramida preživjela sve svjetske katastrofe i da dan danas još ponosno stoji na svom mjestu bez nekih značajnih oštećenja.

Provedena je jedna studija za potrebu koje je napravljena replika piramide od kartona i u koji je postavljen žilet za brijanje. Svaki dan nakon upotrebe žileta istraživač je preko noći ostavljao isti u maketi piramide, a ujutro je taj isti žilet izgledao kao da nije niti korišten. Pokušavao je to objasniti pomoću magnetnog polja koje djeluje na piramidu, ali nikada nije uspio znanstveno to i dokazati. Takvih i sličnih pokušaja je bilo mnogo, ali niti jedan nije dao 
rezultate koji mogu potvrditi pravi razlog građenja piramide i opisati sve sile koje na nju djeluju.

Međutim, nema nejasnoća kada su u pitanju brojevi koji se pojavljuju u analizi. Oni su dobiveni na bezbroj različitih načina i omjera i uvijek su isti, a to su broj $\pi$ i Zlatni broj $\varphi$. Broj $\pi$ je u prvotnim izmjerama prikazan kao 3,16 te varira u svom iznosu zbog mjernih jedinica koje su korištene pri gradnji piramide. Vjeruje se da su Egipćani za izradu piramide imali nešto malo drugačije mjerne jedinice nego danas i postoji puno hipoteza koje vuku poveznicu između tadašnje jedinice palac i današnjeg shvaćanja istog. Uspije li se odgonetnuti kojim mjernim jedinica su se služili gra-

\section{Literatura}

[1] R. Buval, A. Gillbert, Zemlja Ozirisova; Razotkrivanje zagonetke piramida, Mozaik knjiga, Zagreb, 2003.

[2] B. ČEKRLIJA, Vremeplovom kroz matematiku, Laktaši, Grafomark, 2000, http: //www . antonija-horvatek .

from.hr/povijest-matematike/

Vremeplovom-kroz-matematiku-Boris-Cekrlija. pdf (pristupljeno 23. 10. 2016.)

[3] M. GHYKA, Filozofija i mistika broja, Književna zajednica Novog Sada, 1987.

[4] H.W. Janson, A.F. Janson, Povijest Umjetnosti, Stanek, Varaždin, 2013.

[5] B. Janjanin, Analiza izmjere Keopsove piramide, diplomski rad, Geodetski fakultet, Sveučilište u Zagrebu, 2015.

[6] D. KUŠAR, The Golden Section and the Origin of this Name, Journal for Geometry and Graphics 11(1) (2007), 83-92.

[7] Manetho, Od Sincela prema Eusebiju $(f r .7,12) i$ Afrikanu (fr.8 11), London, 1971, (prijevod: W.G. Waddell), http://penelope.uchicago.edu/ Thayer/E/Roman/Texts/Manetho/History_of_ Egypt/1*.html (pristupljeno 23. 10. 2016.)

[8] S. Mehler, Zemlja Ozirisova, Teledisk, Zagreb, 2003.

[9] G. Novak, I. Uranić, Povijest starog Egipta, Školska knjiga, Zagreb, 2002.

[10] C. Nugue, Velike civilizacije svijeta, Extrade, Rijeka, 2000. ditelji i koliko one iznose, taj bi korak zasigurno pomogao u razotkrivanju tajni koje se kriju u dimenzijama Velike piramide.

Dozvolit ćemo si ovdje spomenuti staru tvrdnju koja kaže: "Iako se piramide nalaze u Egiptu, to ne znači da su i egipatske." Može li to ukazivati na činjenicu da je u Egiptu postojao utjecaj neke naprednije civilizacije, zaslužne za izgradnju Velike piramide? Radi se o često postavljanom pitanju, na koje treba pronaći odgovor. Taj je odgovor iznimno značajan, budući da može dovesti do konačnog rješenja brojnih tajni vezanih uz njeno postojanje.

[11] D. PošTić, Misterij piramida, Nova arka, Zagreb, 1996.

[12] T. StrmeČKI, B. KovAČIĆ, Matematičke konstante (1), Poučak 58 (2014).

[13] M. Toth, G. NiElsen, Moć piramida, CID-NOVA, Zagreb, 2000.

[14] M. Tотн, Proročanstva piramida, CID-NOVA, Zagreb, 2001.

[15] http://alizul2.blogspot.hr/2012/01/ secrets-hidden-in-pyramids-of-egypt . html (pristupljeno 12. 3. 2015.)

[16] http://metro-portal.hr/ kako-je-izgradjena-keopsova-piramida/ 13124 (pristupljeno 27. 3. 2015.)

[17] http://pyramidales.blogspot.hr/2011/03/ la-rampe-interieure-deux-niveaux-de-la. html (pristupljeno 20. 5. 2015.)

[18] http://venia-mag.net/ tuska-metal-festival-2005-helsinkipark-15-17-07-2005/civilisations/egypt/ (pristupljeno 29. 5. 2015.)

[19] http://www.ancient-origins.net/ ancient-places-africa-opinion-guestauthors/mathematical-encoding-greatpyramid-002323 (pristupljeno 16. 3. 2015.)

[20] http://www.casopis-gradjevinar.hr/ assets/Uploads/JCE-53-2001-02-06.pdf (pristupljeno 15. 3. 2015.)

[21] http://www.gizapower.com/ (pristupljeno 10. 3. 2015.) 
[22] http://www.gizapyramid.com/ (pristupljeno 10. 3. 2015.)

[23] http://www.gizapyramid.com/newtour5.htm (pristupljeno 10. 5. 2015.)

[24] http://www.irb.hr/Istrazivanja/Zavodi/ Zavod-za-eksperimentalnu-fiziku/ Laboratorij-za-mjerenje-niskihradioaktivnosti/ Odredivanje-starosti-metodom-14C (pristupljeno 21. 9. 2015.)

[25] http://www.jutarnji.hr/life/znanost/ napokon-razotkriven-veliki-misterijznamo-kako-su-drevni-egipcani-gradili-piramide/796414 (pristupljeno 5. 6. 2016.)

[26] http://www. soulsofdistortion.nl/ croatian/SODA_chapter8.html (pristupljeno 23. 6. 2017.)

[27] http://www.studyof oahspe.com/id49.html (pristupljeno 11. 3. 2015.)
[28] https://hr.wikipedia.org/wiki/Piramide_ u_Gizi (pristupljeno 10. 3. 2015.)

[29] https://hr.wikipedia.org/wiki/Popis_ faraona (pristupljeno 17. 6. 2015.)

[30] https://www.google.hr/maps/@30.5427367, $30.486107,287968 \mathrm{~m} /$ data $=$ ! $3 \mathrm{~m} 1 ! 1 \mathrm{e} 3$ (pristupljeno 10. 5. 2016.)

[31] https://www . youtube.com/watch?v= dGH93mt81BA) (pristupljeno 28. 10. 2015.)

\section{Bojan Janjanin}

e-mail: janjanin.bojan@gmail.com

\section{Jelena Beban-Brkić}

e-mail: jbeban@geof.hr

Faculty of Geodesy, University of Zagreb

Kačićeva 26, HR-10000 Zagreb, Croatia 